\title{
Soil properties of secondary forests under shifting cultivation by the Iban of Sarawak, Malaysia in relation to vegetation condition
}

\author{
Sota Tanaka, ${ }^{1, *}$, Mohd Effendi Bin Wasli ${ }^{2}$, Takashi Kotegawa ${ }^{2}$, Logie Seman ${ }^{3}$, John Sabang ${ }^{4}$, \\ Joseph Jawa Kendawang ${ }^{3}$, Katsutoshi SaKURaI ${ }^{2}$ and Yoshinori Morooka ${ }^{1}$ \\ Graduate School of Kuroshio Science, Kochi University, B202, Monobe, Nankoku, 783-8502, Japan \\ ${ }^{2}$ Faculty of Agriculture, Kochi University, B202, Monobe, Nankoku, 783-8502, Japan \\ Forest Department, Sarawak, Kuching, Sarawak, 93660, Malaysia \\ Forest Research Center, Sarawak Forestry Corp., Kuching, Sarawak, 93250, Malaysia \\ *Corresponding author: Sota TANAKA, Tel: 088-864-5183, Fax: 088-864-5183, E-mail: sotatnk@cc.kochi-u.ac.jp
}

ABSTRACT Soil properties under secondary forests were studied in relation to vegetation conditions to clarify the site selection method for shifting cultivation of the Iban in Sarawak, Malaysia. Soils and vegetation were surveyed at 25 suitable sites and 17 unsuitable sites for shifting cultivation, classified by the landowners based on their perceptions through knowledge of vegetation condition. Principal component analysis classified soil properties into three principal components. The first was soil texture and organic matter with high factor loadings of clay content, cation exchange capacity, total $\mathrm{C}$, and total $\mathrm{N}$, and, to a lesser extent, exchangeable $\mathrm{K}$. These properties were little affected by the fallow duration and site suitability. Clay content was regarded as one of important factors related to the levels of organic matter and nutrient retention capacity of the soils. The second component reflected soil acidity and exchangeable bases with high factor loadings of $\mathrm{pH}$, exchangeable $\mathrm{Ca}$ and $\mathrm{Mg}$, exchangeable $\mathrm{Al}$, and $\mathrm{Al}$ saturation. These properties reflected the remnant effects of ash addition and fallow duration. However, no clear differences were apparent in these properties in terms of site suitability. The third component was linked to $N$ availability, including the $C / N$ ratio and exchangeable $\mathrm{NH}_{4}$. The $\mathrm{N}$ availability was higher at suitable sites than at unsuitable sites. At suitable sites, $\mathbf{N}$ availability tended to be higher with increasing fallow age. The $\mathrm{N}$ availability showed a statistically significant correlation with the site score of the first axis obtained from correspondence analysis of plant density, suggesting a strong relationship between $N$ availability and vegetation condition. That relationship was attributable to depletion of the available $\mathbf{N}$ of the soils during cropping and at the initial fallow stage, as well as to improvement of $\mathbf{N}$ availability of soils with increasing length of the fallow period. This finding related to $\mathrm{N}$ availability was consistent with farmers' criteria for fertile land: leaves of trees in fertile land should be dark green. The presence of some specific plant species might be correlated with levels of available $P$ and soil hardness. Results of this study show that the Iban farmers' vegetationbased site-selection method might reflect the ability of secondary forest ecosystems to supply nutrients for rice plants through burning practices.

Key words: indigenous knowledge, site selection, shifting cultivation, soil fertility, Sarawak, Iban

\section{INTRODUCTION}

The knowledge of indigenous farmers about environments and agricultural practices has recently received considerable attention in the context of sustainable agricultural development, forest management, and conservation strategies (UNCED, 1992; Eghenter et al. 2003). In the upland region of Borneo Island, various ethnic groups have practiced shifting cultivation to plant upland rice as their staple food (MacKinnon et al. 1997). Reportedly, these people examine vegetation conditions such as species composition and plant growth or the presence of specific plants as indicators to evaluate land suitability and fertility when selecting new farming sites (e.g., the Benuaq reported by Gönner (2002); the Kenyah by Mackie (1986)). Results of those examinations are combined with other factors such as topography, accessibility to the land, land tenure, labor availability, rituals, and taboos for decision-making related to site selection. However, site selection methods of ethnic 
groups have been studied as an aspect of ethnographic or socioeconomic studies that comprehensively address agricultural or socioeconomic activities. No rigorous ecological survey has been conducted so far on site selection methods. On the other hand, numerous studies have examined the influences of shifting cultivation practices on forest and soil ecosystems in Borneo: the effects of burning on soil ecosystems were evaluated by experimental shifting cultivation practices (Andriesse and Schelhaas, 1987a, b; Kendawang et al. 2004, 2005; Tanaka et al. 2004, 2005); Ishizuka et al. (2000) reported soil characteristics of the land degraded by shifting cultivation. Regeneration processes of secondary forests have been studied by Hashimoto et al. (2000), Okimori and Matius (2000), Ipor and Tawan (2004), and Kendawang et al. (2007). Notwithstanding, few studies have examined changes in soil properties during fallow periods (e.g. Bruun et al. 2006).

The objective of the present study is to clarify the site selection method of the Iban in Sarawak, Malaysia based on the ecological investigation of vegetation and soil properties at various stages of secondary forest. A field survey was conducted at the sites that had been classified in terms of suitability for upland rice cultivation by landowners based on their perception of vegetation condition. In a previous paper (Tanaka et al. 2007), we described alteration of shifting cultivation practices in the study area and analyzed the site selection method based on interviews and vegetation surveys, with special reference to secondary vegetation conditions (species composition, plant density and stem diameter of trees) and the presence of specific indicator plants. This paper presents analyses of soil fertility levels at suitable and unsuitable sites, along with discussion of the effects of fallow duration and vegetation conditions.

\section{MATERIALS AND METHODS}

\section{Study sites and vegetation survey}

Detailed information about study sites and vegetation survey was provided in a previous paper (Tanaka et al. 2007); they are described briefly here. The study was conducted at five longhouses (Rumah in the Iban, Rh) located on the riverbank of the Mujong River in Kapit Division, Sarawak: Rh. Along, Rh. Liok, Rh. Peter, Rh. Anding and Rh. Nawin. All families of the longhouses cultivated upland rice using a shifting cultivation method. The mean annual temperature was about $26^{\circ} \mathrm{C}$ (Meteorological Department, 2003); the mean annual precipitation in the preceding decade, 1994-2003, was
4,300 $\mathrm{mm}$ (Department of Irrigation and Drainage, 2003). The parent materials of soils were derived from sedimentary rocks composed of shale, slate, phyllite, and sandstone with marlstone, calcareous sandstone, conglomerate, and limestone lenses with weak regional metamorphism during the Paleocene to Eocene periods (Yin, 1992). Soils were classified into the Kapit family of the Skeletal Soil Group in the Sarawak soil classification system (Teng, 2003), roughly corresponding to Udorthents of the USDA system (Soil Survey Staff, 1999).

During May-August, 2003, 42 sites in secondary forests with various ages after fallow were selected. They were classified into 25 suitable sites and 17 unsuitable sites for upland rice cultivation by landowners based on their perceptions of vegetation condition. Vegetation surveys were carried out in a $10 \times 10 \mathrm{~m}^{2}$ or $20 \times 20$ $\mathrm{m}^{2}$ quadrat. The name, density and stem diameter at breast height (DBH) of all woody plants were recorded based on the Iban's nomenclature system. The name and density of all other smaller plants, grasses, ferns, tree seedlings, etc., were also recorded at the quadrat or three sub-quadrates $\left(2 \times 2 \mathrm{~m}^{2}\right)$ established within it. Plant specimens were collected and identified with their scientific names at the Botanical Laboratory of Forest Research Center, Kuching. The Iban classify plants principally based on morphology, cultivation status and uses (Tun Jugah Foundation, 2001). Taking into account this fact and the responses of the farmers during survey, the plants observed in the survey were categorized into 11 groups: bamboos, ferns, gingers, grasses and herbs (excluding ginger), vines, palms, rattans, shrubs, trees, wild bananas, and unknowns. The vine group consisted of woody and non-woody vines, but the unknown group consisted of the plants that were unidentifiable by the farmers.

In May, 2004, to discover and assess indicator plants used by the Iban farmers, questions were asked of 33 residents to obtain their opinions of whether a plant encountered during the field survey indicated fertile or infertile land.

\section{Soil sampling and analyses}

Soil samples were collected at depths of $0-10 \mathrm{~cm}$ (surface soils) and 30-40 cm (subsoils) in three soil pits within the quadrat in each of the 42 sites for the vegetation survey. They were mixed well to produce a composite sample for physicochemical analyses. Soil $\mathrm{pH}$ was determined in water or $1 \mathrm{M} \mathrm{KCl}$ in a soil to solution ratio of $1: 5$ using the glass electrode method. Total $\mathrm{C}$ and $\mathrm{N}$ contents (T-C, $\mathrm{T}-\mathrm{N}$ ) were analyzed using a NC analyzer (Sumigraph 
NC-80; Sumika Chemical Analysis Co., Osaka, Japan). The contents of exchangeable bases (Ca, $\mathrm{Mg}, \mathrm{K}$ and $\mathrm{Na}$ ) and the cation exchange capacity (CEC) were measured after successive extraction using $1 \mathrm{M}$ ammonium acetate adjusted to $\mathrm{pH} 7.0$ and $10 \% \mathrm{NaCl}$, respectively. The amount of $\mathrm{NH}_{4}$ replaced by $\mathrm{Na}$ was determined using the steam distillation and titration method, whereas the contents of exchangeable bases were determined by atomic absorption spectrophotometry for $\mathrm{Ca}, \mathrm{Mg}$, and $\mathrm{K}$ and by flame photometry for Na (AA-6800; Shimadzu Corp., Kyoto, Japan). Exchangeable Al, $\mathrm{H}$, and $\mathrm{NH}_{4}$ were extracted with $1 \mathrm{M} \mathrm{KCl}$. Exchange acidity $(\mathrm{Al}+\mathrm{H})$ was determined using the titration method with $0.01 \mathrm{M} \mathrm{NaOH}$ and the content of the exchangeable $\mathrm{Al}$ with $0.01 \mathrm{M} \mathrm{HCl}$. The content of exchangeable $\mathrm{H}$ was calculated as the difference between the values of the exchange acidity and exchangeable Al. The content of exchangeable $\mathrm{NH}_{4}$ was determined using the indophenol blue method (Mulvaney, 1996). The available phosphorus content was measured using the Bray II method (Kuo, 1996). Particle size distribution was determined using the pipette method. Soil hardness was examined at depths of 0-10 and 30-40 $\mathrm{cm}$ using a Yamanaka-type penetrometer.

\section{Data analyses}

As mentioned in a previous paper (Tanaka et al. 2007), at the 42 study sites, totally 252 plant species were recorded. However, most of them occurred rarely and only 70 species occurred relatively commonly, that is, at more than 5 sites of the 42 study sites. Therefore, we assumed that these 70 species were important for site selection of the farmers and used their data for detailed analyses (indicator values and correspondence analysis). The indicator value $\left(I_{N D} V_{A L}\right)$ was calculated to assess the plants as indicators for land fertility from an ecological viewpoint (Dufrêne and Legendre, 1997; see Tanaka et al. 2007). Dufrêne and Legendre (1997) defined indicator species as the most characteristic species found mostly in a single group of a typology and present at most sites belonging to that group. They proposed the $I_{N D} V_{A L}$ value, which is an integrated measure of the relative abundance and relative frequency of species occurrence. In the current paper, correspondence analysis (CA) was performed for plant densities (plant $\mathrm{ha}^{-1}$ ). A computer program (Canoco ver. 4; Microcomputer Power 1998, New York, USA) was used for CA analysis with scaling of interspecies distances, Hill's scaling, and log transformation of the data. Although the $I_{N D} V_{A L}$ value is effective to assess each species as an ecological indicator, this method can not analyze and describe vegetation conditions of a site comprehensively. On the other hand, in CA analysis, although some information on individual species is lost during integration of data into several CA axes, the vegetation condition in each site can be represented as site scores on CA axes. Therefore, in this study, to correlate vegetation conditions (plant density and species composition) with soil properties, the site scores obtained from the CA analysis were compared with soil properties and the site scores obtained from principal component analysis (PCA) of soil properties. The PCA analysis of soil properties was performed using a computer program (Excel Statistics ver. 2004 for Windows; SRI, Tokyo, Japan).

It is noteworthy that the term plant species used in this study is not based on scientific classification but on the Iban nomenclature system. For the Iban farmers, land evaluation and site selection are intended to achieve adequate rice production for their subsistence. Therefore, the term land fertility or soil fertility is practically equivalent to land suitability for shifting cultivation. In this study, for the sake of convenience, suitability (suitable and unsuitable) is used for sites where we surveyed vegetation and soils, whereas land or soil fertility (fertile and infertile) is used in the context of farmers' perceptions.

\section{RESULTS AND DISCUSSION}

\section{CA analysis of vegetation}

Figure 1 portrays ordination diagrams of the site and species scores obtained from CA analysis. Although the cumulative contribution of the first and second axes (CA1 and CA2) was low (25.8\%), site scores were separated along the two axes (Fig. 1a). Along the CA1 axis, sites with shorter fallow durations tended to load positively, whereas sites with longer fallow ages, especially suitable sites, tended to load negatively. Unsuitable sites with fallow ages of 1-3 years scored more positively along the CA1 axis. Along the CA2 axis, five of the suitable sites were grouped separately from the other sites.

The names of species that showed significant $I_{N D} V_{A L}$ values for the cluster in suitable sites and unsuitable sites are also shown in Fig. 1b. As described in a previous paper (Tanaka et al. 2007), comparison of the $I_{N D} V_{A L}$ values and the farmers' perception suggested that seven plant species were effective indicators of infertile land, particularly during the early fallow stages of less than around 3 years. These plants were composed of two species of the fern group, Selap padi (Lycopodiella cernua) and Kemiding (Stenochlaena palustris), two 
(a) site score

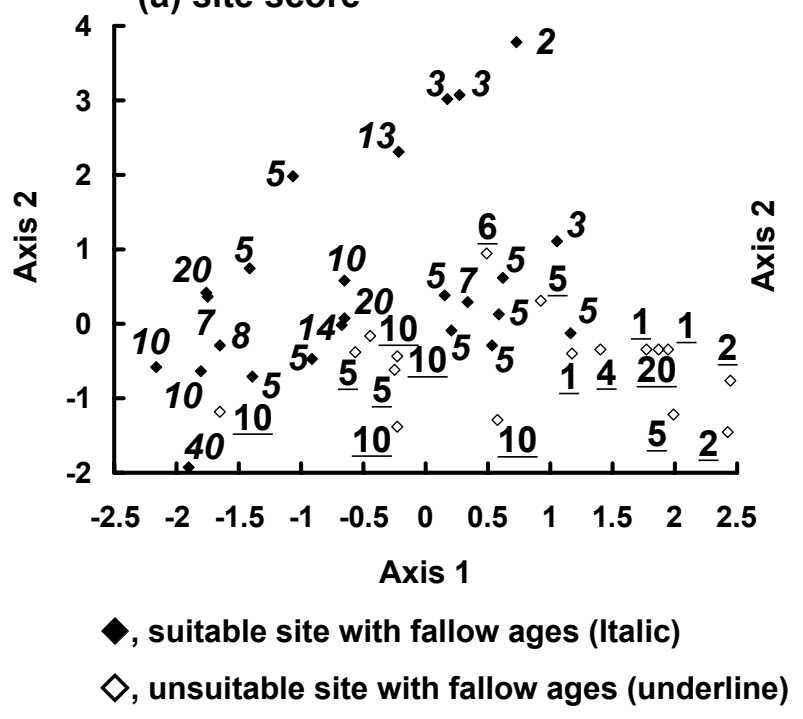

(b) species score

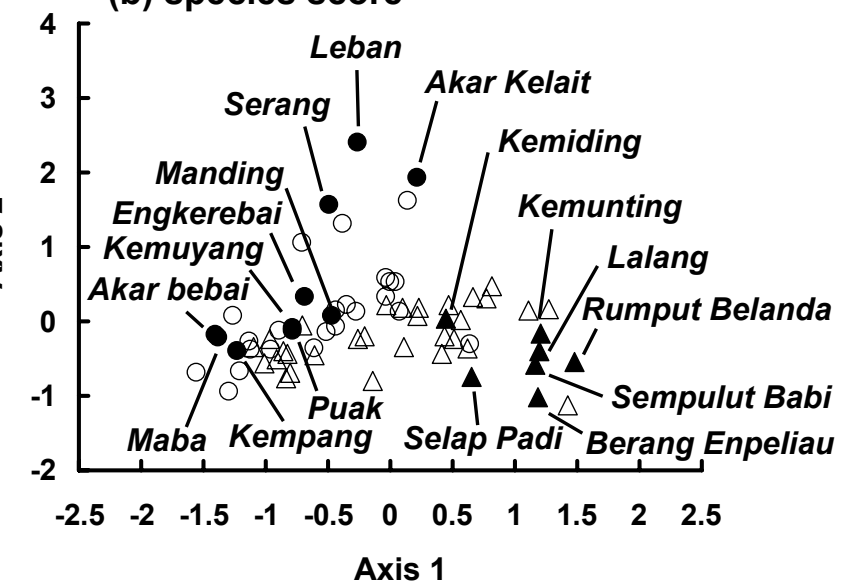

Plants in the cluster of suitable sites

, with significant $\mathrm{I}_{\mathrm{ND}} \mathrm{V}_{\mathrm{Al}}$ values

$O$, with insignificant $I_{\mathrm{ND}} \mathbf{V}_{\mathrm{AL}}$ values

Plants in the cluster of unsuitable sites

$\Delta$, with significant $I_{N D} V_{A L}$ values

$\triangle$, with insignificant $\mathrm{I}_{\mathrm{ND}} \mathrm{V}_{\mathrm{AL}}$ values

Fig. 1. Correspondence analysis ordination diagram of plant density (plant number ha ${ }^{-1}$ ): (a) site scores, (b) species scores.

species of the shrub group, Kemunting (Melastoma polyanthum) and Sempulut babi (Hibiscus sp.), and three species of the grass and herb group, Lalang (Imperata cylindrical), Rumput belanda (Paspalum conjugatum), and Berang empeliau (Isachne albens). Among them, Lalang and Kemunting seemed to be the most important indicators for farmers. On the other hand, the farmers regarded many plants (mostly trees) as indicators for fertile land. Among them, seven species of the tree group (Engkerebai, Psychotria aurantiaca; Serang, Euodia alba; Kumpang, Horsfieldia grandis; Maba, Crypteronia paniculata; Manding, Erythroxylum cuneatum; Leban, Vitex sp.; Puak, Baccaurea macrocarpa), two species of the vine group (Akar Bebai, unidentified; Akar Kelait, Uncaria ferrea), and one species of the ginger group (Kemuyang, Homalomena sagittifolia) showed significant $I_{N D} V_{A L}$ values for suitable sites. However, the growth of trees (stem diameter) was apparently a more important criterion for the Iban to discriminate land fertility in later stages of the fallow period. Results of CA analysis agreed well with these views of indicator plants in a prior paper: the species scores of the seven plants indicating infertile land were allocated around the site scores of the unsuitable sites with short fallow ages, although the separation of site and species scores with longer fallow ages was insufficient in terms of site suitability. Therefore, the results of $\mathrm{CA}$ analysis might represent vegetation conditions with appropriately reflecting the distribution of plant species that are important for site selection.

\section{Characteristics of the studied soils}

Table 1 shows the average, minimum and maximum values of soil physicochemical properties at suitable and unsuitable sites. Soils at both suitable and unsuitable sites were strongly acidic, with $\mathrm{pH}\left(\mathrm{H}_{2} \mathrm{O}\right)$ of less than 6 . The soil texture class varied widely, but many soils were clayey. The contents of exchangeable bases were low compared with that of exchangeable $\mathrm{Al}$, resulting in a high level of $\mathrm{Al}$ saturation, especially in subsoils.

For the surface soil properties, PCA analysis was performed (Table 2). The cumulative contribution from the first to the third principal components was $72.5 \%$. Factor loadings of the first principal component (PC1) were high for soil texture, CEC, T-C, and T-N, and to a lesser extent, exchangeable K. Therefore, the PC1 represents intrinsic properties of the soils related to soil texture and organic matter, as discussed below. Because the second component (PC2) showed high positive factor loadings for $\mathrm{pH}$, exchangeable $\mathrm{Ca}$ and $\mathrm{Mg}$ and high negative loadings for exchangeable $\mathrm{Al}$ and $\mathrm{Al}$ saturation, the $\mathrm{PC} 2$ is inferred to reflect soil acidity and exchangeable bases. On the other hand, PC3 showed a high positive factor loading for $\mathrm{C} / \mathrm{N}$ ratio and a high negative factor loading for exchangeable 
Table 1. Physicochemical properties of the soils studied.

\begin{tabular}{|c|c|c|c|c|c|}
\hline \multirow{2}{*}{$0-10 \mathrm{~cm}$} & & \multicolumn{2}{|c|}{ Suitable sites $(n=25)$} & \multicolumn{2}{|c|}{ Unsuitable sites $(n=17)$} \\
\hline & & Average & (min.-max.) & Average & (min.-max.) \\
\hline $\mathrm{pH}\left(\mathrm{H}_{2} \mathrm{O}\right)$ & & 4.95 & $(4.49-5.57)$ & 4.92 & $(4.40-5.65)$ \\
\hline $\mathrm{pH}(\mathrm{KCl})$ & & 3.67 & $(3.50-3.96)$ & 3.66 & $(3.32-4.16)$ \\
\hline Total C & $\left(\mathrm{g} \mathrm{kg}^{-1}\right)$ & 32.1 & $(13.9-42.4)$ & 32.5 & $(15.4-52.4)$ \\
\hline Total N & $\left(\mathrm{g} \mathrm{kg}^{-1}\right)$ & 2.75 & $(1.32-3.64)$ & 2.51 & $(1.03-3.28)$ \\
\hline $\mathrm{C} / \mathrm{N}$ ratio ${ }^{* *}$ & & 11.6 & $(6.82-13.7)$ & 13.2 & $(9.1-16.3)$ \\
\hline CEC & $\left(\mathrm{cmolc} \mathrm{kg}^{-1}\right)$ & 20.37 & $(6.61-25.5)$ & 19.69 & $(6.78-29.28)$ \\
\hline Exchangeable $\mathrm{Ca}$ & $\left(\mathrm{cmolc} \mathrm{kg}^{-1}\right)$ & 0.83 & $(0.08-2.57)$ & 1.05 & $(0.04-3.78)$ \\
\hline Exchangeable Mg & $\left(\mathrm{cmolc} \mathrm{kg}^{-1}\right)$ & 0.79 & $(0.16-1.52)$ & 0.74 & $(0.06-1.85)$ \\
\hline Exchangeable $\mathrm{K}^{* *}$ & $\left(\mathrm{cmolc} \mathrm{kg}^{-1}\right)$ & 0.28 & $(0.14-0.40)$ & 0.20 & $(0.07-0.43)$ \\
\hline Exchangeable Al & $\left(\mathrm{cmolc} \mathrm{kg}^{-1}\right)$ & 3.50 & $(0.52-7.58)$ & 3.85 & $(0.10-7.78)$ \\
\hline Sum of exchangeable bases & $\left(\mathrm{cmolc} \mathrm{kg}^{-1}\right)$ & 1.94 & $(0.54-4.19)$ & 2.01 & $(0.26-5.83)$ \\
\hline ECEC & $\left(\mathrm{cmolc} \mathrm{kg}^{-1}\right)$ & 5.44 & $(1.94-9.02)$ & 5.87 & $(1.28-9.79)$ \\
\hline $\mathrm{Al}$ saturation & (\%) & 59.8 & (12.6-90.8) & 64.0 & $(1.6-96.5)$ \\
\hline Exchangeable $\mathrm{NH}_{4}{ }^{* *}$ & $\left(\mathrm{cmolc} \mathrm{kg}^{-1}\right)$ & 0.35 & $(0.06-0.97)$ & 0.20 & $(0.08-0.47)$ \\
\hline Available $\mathrm{P}^{*}$ & $\left(\mathrm{mg} \mathrm{kg}^{-1}\right)$ & 7.5 & $(2.3-15.9)$ & 30.2 & $(6.3-236.1)$ \\
\hline Clay & $(\%)$ & 42.1 & $(10.0-58.4)$ & 37.6 & $(9.1-51.2)$ \\
\hline Silt & $(\%)$ & 29.1 & $(9.1-44.1)$ & 27.3 & $(12.0-35.9)$ \\
\hline Sand & $(\%)$ & 28.9 & $(11.4-81.0)$ & 35.0 & $(15.1-75.8)$ \\
\hline Hardness & $(\mathrm{mm})$ & 15.0 & $(11.3-17.0)$ & 13.9 & $(5.6-18.3)$ \\
\hline \multirow[t]{2}{*}{$30-40 \mathrm{~cm}$} & & \multicolumn{2}{|c|}{ Suitable sites $(n=25)$} & \multicolumn{2}{|c|}{ Unsuitable sites $(n=17)$} \\
\hline & & Average & (min.-max.) & Average & (min. $-\max )$. \\
\hline $\mathrm{pH}\left(\mathrm{H}_{2} \mathrm{O}\right)$ & & 4.99 & $(4.59-5.46)$ & 4.86 & $(4.62-5.10)$ \\
\hline $\mathrm{pH}(\mathrm{KCl})$ & & 3.78 & $(3.61-3.94)$ & 3.76 & $(3.55-3.94)$ \\
\hline Total C & $\left(\mathrm{g} \mathrm{kg}^{-1}\right)$ & 8.8 & $(3.8-14.5)$ & 8.4 & $(3.5-14.6)$ \\
\hline Total N & $\left(\mathrm{g} \mathrm{kg}^{-1}\right)$ & 1.24 & $(0.51-2.13)$ & 1.07 & $(0.40-1.65)$ \\
\hline $\mathrm{C} / \mathrm{N}$ ratio ${ }^{* *}$ & & 7.1 & $(5.3-8.5)$ & 8.2 & $(5.0-13.6)$ \\
\hline CEC & $\left(\mathrm{cmolc} \mathrm{kg}^{-1}\right)$ & 14.36 & $(4.56-18.9)$ & 15.01 & $(6.53-21.54)$ \\
\hline Exchangeable $\mathrm{Ca}$ & $\left(\mathrm{cmolc} \mathrm{kg}^{-1}\right)$ & 0.10 & (trace-0.34) & 0.08 & (trace-0.23) \\
\hline Exchangeable $\mathrm{Mg}^{*}$ & $\left(\mathrm{cmolc} \mathrm{kg}^{-1}\right)$ & 0.25 & $(0.02-0.94)$ & 0.13 & (trace-0.38) \\
\hline Exchangeable $\mathrm{K}^{*}$ & $\left(\mathrm{cmolc} \mathrm{kg}^{-1}\right)$ & 0.10 & $(0.04-0.17)$ & 0.07 & (trace-0.14) \\
\hline Exchangeable Al & $\left(\mathrm{cmolc} \mathrm{kg}^{-1}\right)$ & 3.91 & $(1.38-6.46)$ & 3.89 & $(1.77-6.67)$ \\
\hline Sum of exchangeable bases* & $\left(\mathrm{cmolc} \mathrm{kg}^{-1}\right)$ & 0.48 & $(0.09-1.37)$ & 0.30 & $(0.02-0.70)$ \\
\hline ECEC & $\left(\mathrm{cmolc} \mathrm{kg}^{-1}\right)$ & 4.39 & $(1.64-6.82)$ & 4.19 & $(1.79-7.13)$ \\
\hline $\mathrm{Al}$ saturation & (\%) & 87.7 & $(66.1-96.7)$ & 92.7 & $(77.7-98.8)$ \\
\hline Exchangeable $\mathrm{NH}_{4}{ }^{*}$ & $\left(\mathrm{cmolc} \mathrm{kg}^{-1}\right)$ & 0.09 & $(0.04-0.22)$ & 0.07 & $(0.03-0.19)$ \\
\hline Available $\mathrm{P}^{*}$ & $\left(\mathrm{mg} \mathrm{kg}^{-1}\right)$ & 1.5 & $(0.9-4.0)$ & 3.1 & $(1.4-10.7)$ \\
\hline Clay & (\%) & 41.4 & $(14.2-60.1)$ & 36.4 & $(17.5-51.4)$ \\
\hline Silt & $(\%)$ & 28.2 & $(1.8-42.7)$ & 31.4 & $(14.6-62.2)$ \\
\hline Sand & $(\%)$ & 30.5 & $(8.8-71.7)$ & 32.2 & (15.9-67.9) \\
\hline Hardness & $(\mathrm{mm})$ & 14.6 & $(12.6-20.2)$ & 14.2 & $(4.31-18.5)$ \\
\hline
\end{tabular}

ECEC, effective CEC, sum of exchangeable bases and Al, Al saturation, ratio of exchangeable Al to ECEC. Hardness was measured using a Yamanaka-type penetrometer. ", ${ }^{* *}$ Significant differences between suitable and unsuitable sites, respectively, at $5 \%$ and $1 \%$ levels using Student's $t$-test. 
Table 2. Factor loadings of surface soil properties by PCA analysis.

\begin{tabular}{lccc}
\hline & PC1 & PC2 & PC3 \\
Contribution (\%) & 35.6 & 27.5 & 9.5 \\
\hline $\mathrm{pH}\left(\mathrm{H}_{2} \mathrm{O}\right)$ & -0.35 & 0.82 & -0.05 \\
$\mathrm{pH}(\mathrm{KCl})$ & -0.20 & 0.76 & -0.32 \\
$\mathrm{~T}-\mathrm{C}$ & 0.69 & 0.33 & 0.22 \\
$\mathrm{~T}-\mathrm{N}$ & 0.77 & 0.32 & -0.15 \\
$\mathrm{C} / \mathrm{N}$ ratio & -0.11 & 0.09 & 0.64 \\
$\mathrm{CEC}$ & 0.93 & 0.02 & 0.20 \\
Exchangeable $\mathrm{Ca}$ & 0.02 & 0.79 & 0.38 \\
Exchangeable $\mathrm{Mg}$ & 0.34 & 0.78 & 0.23 \\
Exchangeable K & 0.61 & 0.49 & -0.04 \\
Exchangeable $\mathrm{Al}$ & 0.42 & -0.86 & 0.12 \\
ECEC & 0.66 & -0.48 & 0.37 \\
Al saturation & 0.10 & -0.95 & -0.12 \\
Exchangeable $\mathrm{NH} 4$ & 0.35 & 0.33 & -0.53 \\
Available P & -0.44 & 0.03 & 0.40 \\
Clay & 0.93 & 0.01 & 0.01 \\
Silt & 0.83 & 0.08 & 0.08 \\
Sand & -0.95 & -0.04 & -0.04 \\
Hardness & 0.63 & -0.10 & -0.52 \\
\hline
\end{tabular}

charges of clay minerals were predominant under acidic conditions. In terms of the fallow duration and site suitability, no clear tendencies were apparent for clay, T-C, or T-N contents, or for the CEC value (Fig. 2). These results show that the clay content was one of the important factors related to the levels of organic matter and nutrient retention capacity of the soils, probably influencing the nutrient status of the soils to a certain extent. It is noteworthy that the T-C and T-N contents and the $\mathrm{CEC}$ value were also likely to be affected by the inputoutput balance of soil organic matter during the fallow period, through inputs of litterfall and output by decomposition. The exchangeable $\mathrm{K}$ will be discussed in the next section.
$\mathrm{NH}_{4}$, representing a N-availability-related property (but negatively). Factor loadings of available $\mathrm{P}$ were low for all PCs.

The following discussion of soil properties will be conducted based on this categorization. Because subsoil properties showed similar but less marked tendencies than those of the surface soils, we will chiefly use the results of surface soils for further discussion.

\section{Soil texture and organic matter-related properties}

High correlation was observed between T-C and clay contents in both the surface soils and subsoils: $r=0.552^{* *}$ and $r=0.451^{* *}$, respectively. They are ascribable to organic matter stabilization of soils by formation of stable organo-mineral complexes (Ohta et al. 2000). The CEC value was correlated both with T-C and clay contents in the surface soils ( $r=0.665^{* *}$ and $r=0.898^{* *}$, respectively) and only with clay content in the subsoils $\left(r=0.769^{* *}\right)$. For the surface soils, the equation of $\mathrm{CEC}=0.245$ $\mathrm{T}^{-C^{* *}}+0.763$ Clay $^{* *}\left(r=0.921^{* *}\right)$ was obtained from a standardized multiple regression analysis, suggesting a larger contribution of negative charges derived from clay minerals to the level of the CEC than from soil organic matter. Because the effective CEC (ECEC) values were much lower than the $\mathrm{CEC}$ values, permanent negative

\section{Soil acidity and exchangeable bases-related properties in relation to fallow period length}

Figure 3 shows the relationship between soil properties related to $\mathrm{PC} 2$ and the fallow duration. The level of $\mathrm{pH}$, the contents of exchangeable $\mathrm{Ca}, \mathrm{Mg}$, and $\mathrm{Al}$, and the level of $\mathrm{Al}$ saturation reflected the remaining effects of ash addition and the fallow duration. These soil properties in early stages of the fallow period varied widely among sites, whereas those at later stages of the fallow period, with a few exceptions, more clearly indicated the acidic nature of the soils. Many researchers have reported (Juo and Manu, 1996; Giardina et al. 2000; Tanaka et al. 2004, 2005) that ash addition to the soils at burning time mitigates soil acidity and increases the levels of exchangeable bases, which influences depend on the amount of ash, the soil acidity level, and the ability of the soils to adsorb basic cations contained in the ash. During the cropping period, the absolute loss of exchangeable bases from the soils is inevitable through removal as crops, leaching, and erosion (Juo and Manu, 1996; Tanaka et al. 2004, 2005) as well as through volatilization during combustion (Giardina et al. 2000). During the fallow period, the loss of exchangeable bases from the soils and concomitant soil acidification occur because of leaching and uptake by recovering secondary vegetation. 


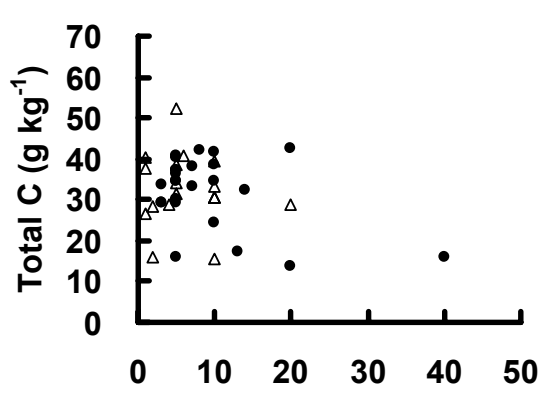

Fallow duration (yrs)

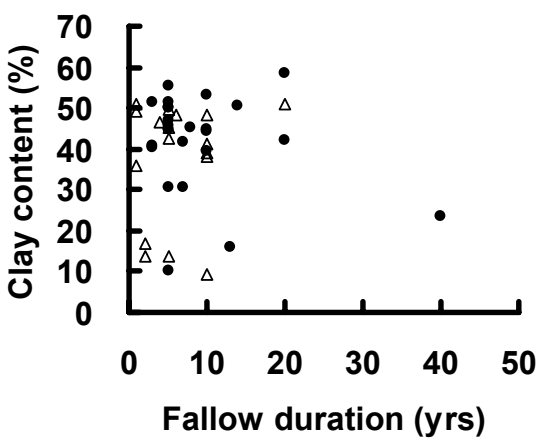

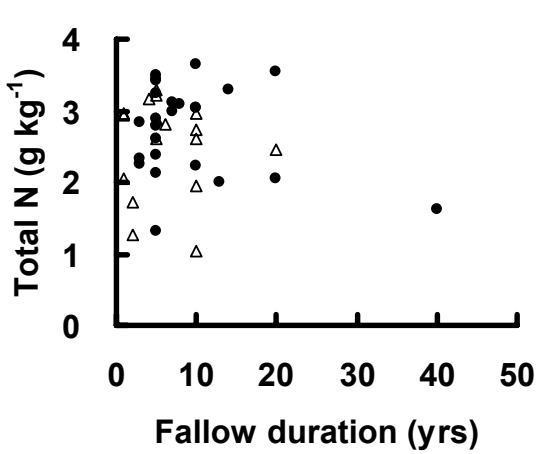

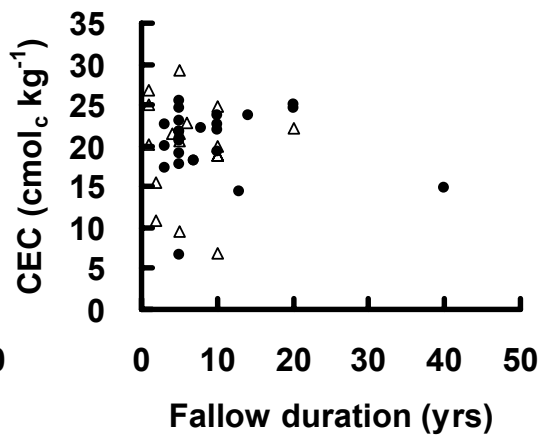

Fig. 2. Total C, total N, clay content and CEC of the surface soils: closed circles, suitable sites; open triangles, unsuitable sites.

Consequently, the great variation of soil properties at the early fallow stages could be ascribed to the remnant ash effects, which depend on the balance between the amount of ash added to soils and the loss of exchangeable bases from the soils. With increasingly long fallow duration, the ash effects disappear and most exchangeable bases of the soils are taken up by recovering plants, in addition to the leaching loss, resulting in acidification of soils (Juo and Manu, 1996; Tanaka et al. 1997). Although the farmers applied chemical fertilizers, the application rate was of about one 50-kg fertilizer bag per acre ( $0.407 \mathrm{ha}$ ) (Tanaka et al. 2007), which was likely to be too low to affect the level of exchangeable bases.

No clear difference was apparent in terms of site suitability, except for exchangeable $\mathrm{K}$. It is noteworthy that the exchangeable $\mathrm{K}$ showed the higher factor loading in $\mathrm{PC} 1$ than in $\mathrm{PC} 2$ although the difference in the factor loadings between the two PCs was not large (Table 2). Although the change in exchangeable $\mathrm{K}$ contents was unclear in terms of fallow duration, it was significantly higher at suitable sites than at unsuitable sites (Table 1). These results indicate that the dynamics of exchangeable $\mathrm{K}$ under secondary forest was different from those of exchangeable $\mathrm{Ca}$ and $\mathrm{Mg}$ and that the level of exchangeable $\mathrm{K}$ might depend on soil texture, the levels of soil organic matter, and the nutrient retention capacity of the soils. Although further study should be required to clarify the difference in the levels of exchangeable $\mathrm{K}$ between suitable and unsuitable sites, the balance including the following factors as well as the nutrient retention capacity of the soils might be related; 1) $K$ contained in ash and exchangeable $K$ of the soils showed higher mobility from the surface soils to deeper soil layers after burning practices, compared with those of $\mathrm{Ca}$ and $\mathrm{Mg}$ (Tanaka et al. 2005), 2) in the study area, weeding was performed manually during rice cropping season (Tanaka et al. 2007) while only the ear of rice was harvested at harvesting time. The weeded plants and rice straw were left in the field, which resulted in an addition of nutrients to surface soils through decomposition process, and 3) vigorous secondary growth and succession in suitable sites could result in pumping up of nutrients from deeper soil layers to surface soils and accumulation of nutrients at surface soils, compared with unsuitable sites where vegetation recovery was poor.

$\mathrm{N}$-availability-related properties in terms of site suitability and fallow duration

The $\mathrm{C} / \mathrm{N}$ ratio was significantly lower and the content of exchangeable $\mathrm{NH}_{4}$ was significantly higher at the suitable sites than those at the unsuitable sites (Table 1). At the suitable sites, the $\mathrm{C} / \mathrm{N}$ ratio significantly decreased with increasing fallow duration (Fig. $4 ; r=0.559^{* *}$ ). The contents of exchangeable $\mathrm{NH}_{4}$ tended to increase with 

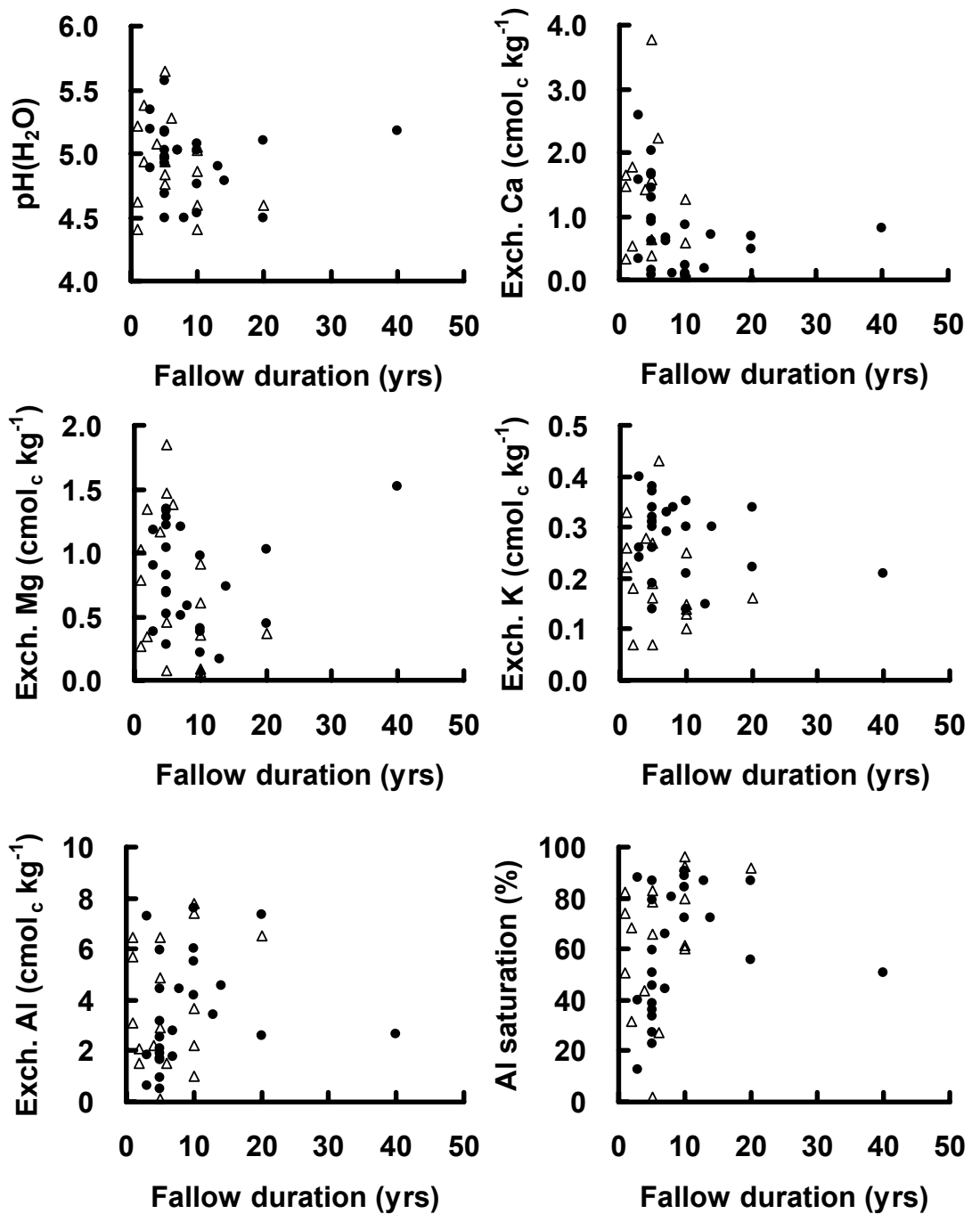

Fig. 3. pH, exchangeable bases and Al, and Al saturation of the surface soils: closed circles, suitable sites; open triangles, unsuitable sites.
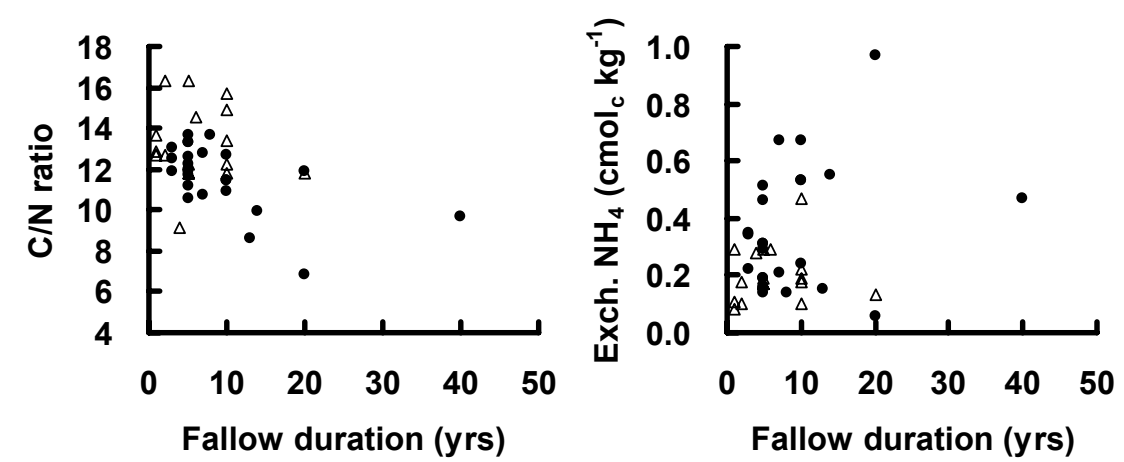

Fig. 4. $\mathrm{C} / \mathrm{N}$ ratio and exchangeable $\mathrm{NH}_{4}$ of the surface soils: closed circles, suitable sites; open triangles, unsuitable sites. 


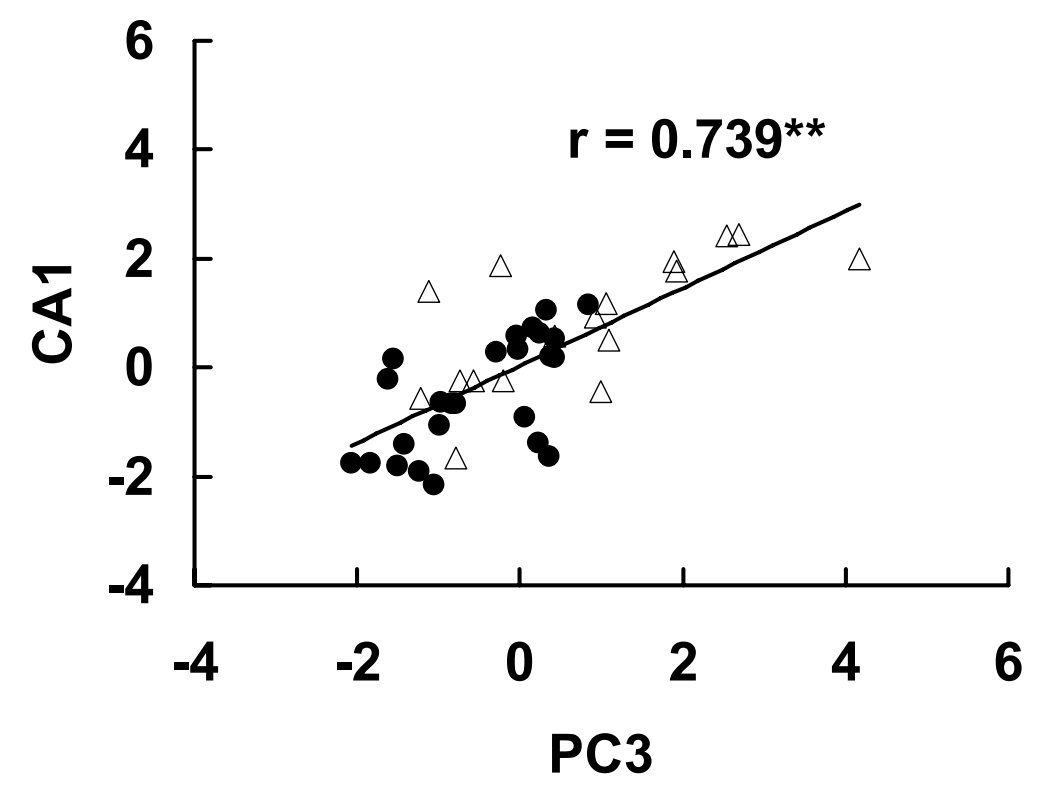

Fig. 5. Relationship between site scores on the PC3 derived from PCA analysis and the CA1 derived from CA analysis: closed circles, suitable sites; open triangles, unsuitable sites.

increasing fallow duration (Fig. 4; $r=0.398^{*}$ when the outlying data from one site with the fallow age of 20 years was excluded). The PC3 score showed a significant correlation with the site score of the CAl obtained from plant densities ( $r=0.739^{* *}$; Fig. 5$)$. The $\mathrm{C} / \mathrm{N}$ ratio and contents of exchangeable $\mathrm{NH}_{4}$ also showed significant correlations with the site score $\left(r=0.372^{*}\right.$ and $r=-0.534^{* *}$, respectively). In contrast, other soil properties, including the $\mathrm{PC} 1$ and $\mathrm{PC} 2$ scores, showed no correlation with the CA1 score. The CA2 score showed no correlation with soil properties or the PC scores.

Thus, the $\mathrm{N}$ availability was higher at suitable sites, especially in later fallow stages, than at the unsuitable sites. The higher correlation coefficient between the $\mathrm{PC} 3$ and $\mathrm{CA} 1$ than between either of $\mathrm{C} / \mathrm{N}$ ratio or exchangeable $\mathrm{NH}_{4}$ content and the $\mathrm{CA} 1$ implies that $\mathrm{N}$ availability containing both the quality of soil organic matter $(\mathrm{C} / \mathrm{N}$ ratio) and the actual amount of mineral $\mathrm{N}$ (exchangeable $\mathrm{NH}_{4}$ in this study) are more important factors for site suitability evaluated by the farmers. Two reasons might explain the difference in $\mathrm{N}$ availability between suitable and unsuitable sites: The first is the depletion of available $\mathrm{N}$ of soils during cropping and at the initial fallow stages. Kendawang et al. (2005) reported that, in experimental shifting cultivation, the available $\mathrm{N}$ fraction (the sum of mineral $\mathrm{N}$, microbial $\mathrm{N}$, and readily extractable organic $\mathrm{N}$ ) was rapidly depleted, even in clayey soils during rice cropping, but that the contents of T-N did not change markedly. During the early fallow period, especially at the unsuitable sites where non-leguminous species predominated, the depleted available $\mathrm{N}$ of the soils could not be restored but might be further lowered because of plant uptake. The second reason is the improvement of $\mathrm{N}$ availability of soils with increasing fallow duration. This could be ascribable to the available $\mathrm{N}$-accumulation process of the soils during the fallow period, including $\mathrm{N}$ addition through biological fixation and litterfall. A large addition of fresh organic $\mathrm{N}$ through these processes is expected in the suitable sites at later stages of fallow period, where larger trees grew. Although the level of T-N was not correlated to the length of fallow duration (Fig. 2), the decrease in $\mathrm{C} / \mathrm{N}$ ratio with increasing fallow duration at suitable sites (Fig. 4) suggests that the quality of soil organic $N$ changed to being easily mineralizable. In contrast, at unsuitable sites, $\mathrm{N}$ availability levels were low, even at later stages, probably because of the low level of $\mathrm{N}$ availability at the initial fallow stage and the lack of $\mathrm{N}$ sources under poorly growing vegetation. This finding, which is related to $\mathrm{N}$ availability, is consistent with the farmers' criterion for fertile land: that the leaves of trees in fertile land should be dark green (Tanaka et al. 2007), which could reflect plentiful $\mathrm{N}$ supply from soils. In contrast, it is somewhat difficult to interpret another criterion 'trees grow straight at fertile land'. However, this might imply vigorous growth of tree species under sufficient nutrient supply 


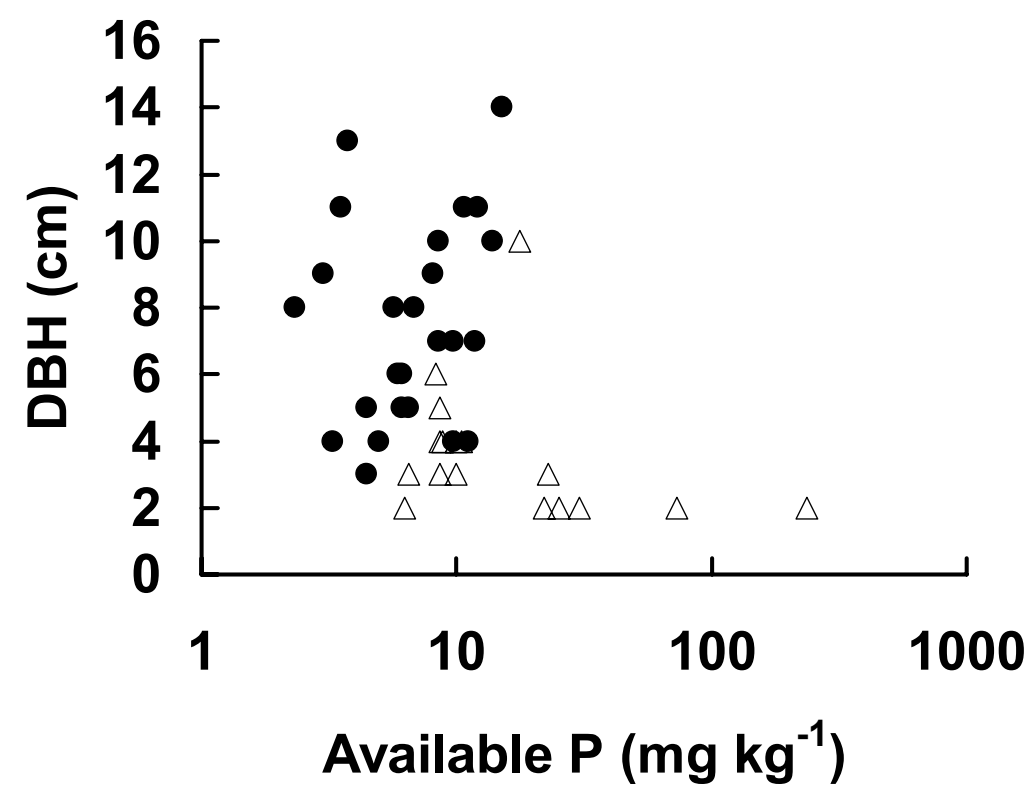

Fig. 6. Relationship between available $P$ of the surface soils and average DBH of trees. The content of available $P$ is logtransformed: closed circles, suitable sites; open triangles, unsuitable sites.

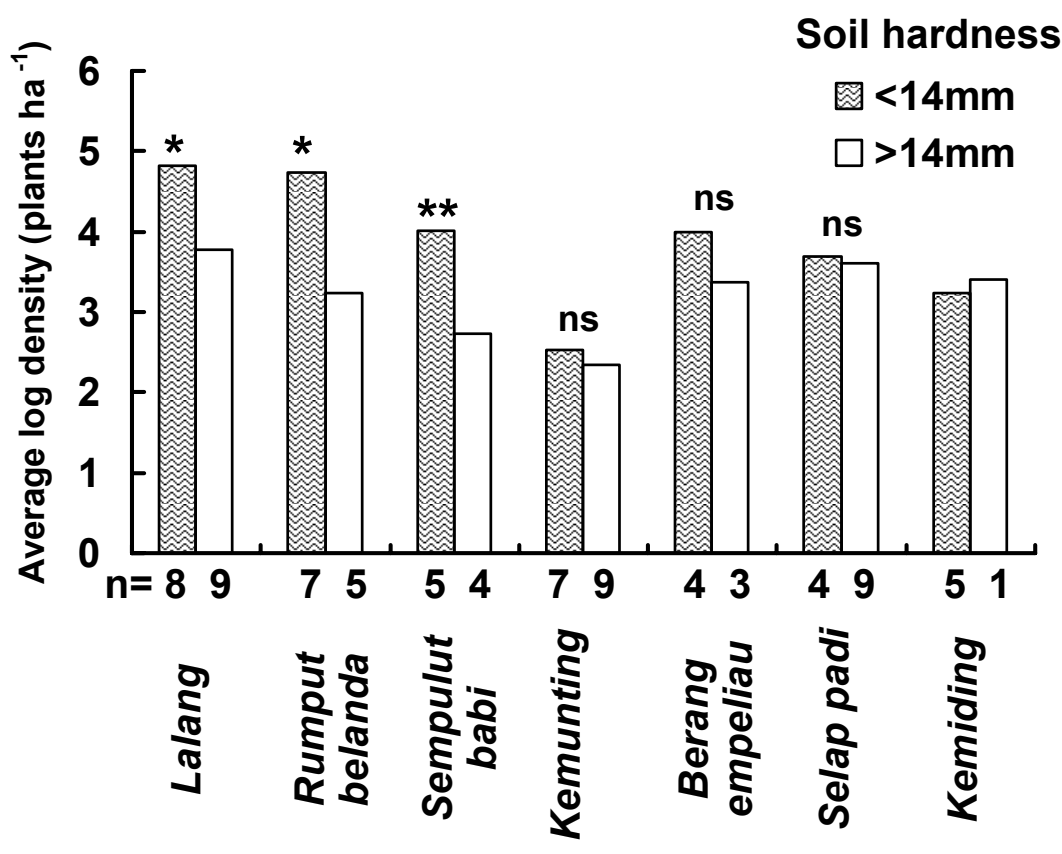

Fig. 7. Relationship between soil hardness and the average density of plants indicating infertile land with significant $I_{N D} V_{A L}$ values. The average density is calculated for the sites with soil hardness less than $14 \mathrm{~mm}$ and more than 14 mm measured by a Yamanaka-type penetrometer. *, **, significant difference at $5 \%$ and $1 \%$ levels, respectively, using Student's $t$-test. ns, no significant difference. $n$, number of the sites where the plant occurred. 
from soils, probably N.

\section{Relationship between other soil properties and vegetation}

The levels of available $\mathrm{P}$ were extremely high at some unsuitable sites, leading to the significant difference between the suitable and unsuitable sites (Table 1). The levels at two unsuitable sites with preceding fallow periods of 2 and 5 years were extremely high: 236 and $73.1 \mathrm{mg} \mathrm{kg}^{-1}$, respectively. Comparison with the average DBH might provide an explanation (Fig. 6). In this figure, the unsuitable sites at which the DBH was less than 2-3 $\mathrm{cm}$ showed a high value of available P. In general, $\mathrm{P}$ is less vulnerable to leaching loss because of its immobility in soils. Therefore, great amounts of available P suggest that some portion of $\mathrm{P}$ which had been added as ash or fertilizer was unused by plants and remained in the soil. In addition, the two soil samples with the extremely high values of available $\mathrm{P}$ might be collected from the spot where large biomass had been burnt or chemical fertilizer had been applied.

Interesting relationships were found among some soil properties and specific plant species. As mentioned earlier, the five suitable sites were characterized by the predominance of Leban, Serang, and Akar Kelait and separated from other sites along the CA2 axis (Fig. 1). Contents of available $\mathrm{P}$ were significantly lower at these sites $\left(4.1 \mathrm{mg} \mathrm{kg}^{-1}\right)$ than at other suitable sites $(8.3 \mathrm{mg}$ $\left.\mathrm{kg}^{-1}\right)$. On the other hand, Fig. 7 shows the relationship between soil hardness, as measured with a Yamanakatype penetrometer, and the average density of plants indicating infertile land with significant $I_{N D} V_{A L}$ values. The plants were classified into two groups. The first group showed higher density at sites with soil hardness less than $14 \mathrm{~mm}$. This group comprised Lalang, Rumput beranda, and Sempulut babi. The other group included Kemunting, Berang empeliau, Selap padi, and Kemiding, of which densities were unaffected by soil hardness. Because these relationships suggest that the presence or density of several specific plants in secondary forests might be correlated with specific soil properties, further studies should be undertaken to assess the influence of soil properties on vegetation composition and growth during the fallow period.

\section{Abilities of soils to supply nutrients to rice plants in relation to site suitability \\ Farmers perceived sites to be unsuitable for shifting cultivation when the fallow age of the sites was less than 3 years, and the sites were dominated by plants indicating}

infertile land (Lalang, Kumunting, etc.). Soil fertility under such vegetation was low in $\mathrm{N}$ availability although some soils showed less acidic condition with higher contents of exchangeable $\mathrm{Ca}$ and $\mathrm{Mg}$ (Fig. 3) due to the remaining effect of ash.

With increasing fallow duration, tree species, most of which the farmers perceived to indicate fertile land, replace the pioneer species such as grasses, ferns and shrubs. At this stage, the farmers investigate the stem diameter of trees and select sites at which the trees recovered well (Tanaka et al. 2007). The N availability of soils was higher at sites with well-growing vegetation than at sites with poor vegetation growth. In shifting cultivation practices with little or no fertilizer application, the stimulation of $\mathrm{N}$ mineralization from soil organic matter and microorganisms by burning is more important for $\mathrm{N}$ supply to rice plants than $\mathrm{N}$ input through ash addition because most $\mathrm{N}$ contained in aboveground biomass would be lost to the atmosphere through vaporization (Juo and Manu, 1996; Giardina et al. 2000; Kendawang et al. 2005). High N availability during the fallow period indicates that $\mathrm{N}$ mineralization is inducible rapidly and plentifully through burning practices (Tanaka et al. 2001). In contrast, soils showed more acidity and lower contents of exchangeable bases without clear differences between suitable and unsuitable sites. However, the amounts of basic cations accumulated in the aboveground biomass seemed to be considerably larger at the suitable sites than at the unsuitable sites. Figure 8 shows the aboveground biomass of trees, as estimated using the allometry equation calculated for aboveground biomass of trees in old secondary forests in Sarawak (Ninomiya, personal communication); Biomass $=0.0766 \times \mathrm{DBH}^{2.4944}$ (for trunks) $+0.0128 \times \mathrm{DBH}^{2.4691}$ (for branch) $+0.0224 \times \mathrm{DBH}^{1.8918}$ (for leaves). The equation was used without any modification, although most of

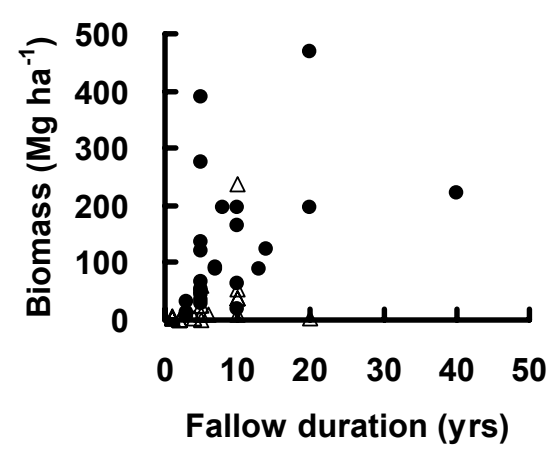

Fig. 8. Estimation of aboveground biomass of trees: closed circles, suitable sites; open triangles, unsuitable sites. 
our study sites were young secondary forests. It is also noteworthy that this estimation incorporates only the tree biomass. In Fig. 8, tree biomass at suitable sites was markedly higher than that at unsuitable sites and increased with increasing fallow ages $\left(r=0.428^{*}\right)$. Some sites with very large quantities of biomass included a few large DBH trees, which had probably remained uncut during the previous round(s) of shifting cultivation. According to the results of the experimental shifting cultivation (Kendawang et al. 2004, 2005a; Tanaka et al. 2004, 2005), when at least $100 \mathrm{Mg} \mathrm{ha}^{-1}$ of the vegetation biomass was burned on clayey soils, sufficient amounts of ash were produced to ameliorate acidic condition of soils and increased the contents of exchangeable bases for one-time cropping of upland rice. In the present study, the biomass at the suitable sites would reach to the level of $100 \mathrm{Mg} \mathrm{ha}^{-1}$ after 7-10 years left fallow (Fig. 8). It would thereby be able to supply sufficient amounts of ash. Our results also suggest that burning even about $50 \mathrm{Mg} \mathrm{ha}^{-1}$ of tree biomass is sufficient to produce rice yields that would sustain a family for 1 year (Tanaka et al. 2007). In this case, the biomass derived from other plant groups might contribute to the total biomass that is burned.

\section{CONCLUSION}

Soil properties under secondary forest could be classified into three principal components by using the PCA. The $\mathrm{PC} 1$ represented soil texture and organic matter which were little affected by the fallow duration and site suitability. The PC2 represented the levels of soil acidity and exchangeable bases. Although these properties reflected the remnant effects of ash addition and fallow duration, no relationship was observed in terms of site suitability. However, at suitable sites, larger aboveground biomass was accumulated compared with unsuitable sites, which could supply plentiful nutrients (mainly basic cations and $\mathrm{P}$ ) as ash addition to surface soils at burning time. The PC3 was linked to $\mathrm{N}$ availability of the soils. The $\mathrm{N}$ availability could be correlated with vegetation condition assessed by correspondence analysis. The $\mathrm{N}$ availability was higher at suitable sites than at unsuitable sites, indicating that $\mathrm{N}$ mineralization of soils in suitable site is inducible rapidly and plentifully through burning practices. Such effects of nutrient supply through ash addition and $\mathrm{N}$ mineralization enhanced by burning practice could secure rice production sufficient for farmers' subsistence (Tanaka et al. 2007). Thus, in conclusion, the site selection method of Iban farmers based on secondary vegetation can be correlated with the ability of secondary forest ecosystems to supply nutrients for rice plants through burning practices. In contrast, the presence of plants indicating infertile land might be related with low $\mathrm{N}$ availability and slight accumulation of nutrients in aboveground vegetation.

These relationships between soil fertility and vegetation might be incorporated into cropping-fallow management and appropriate fertilizer application strategies as the criterion of soil fertility. However, nowadays, in many upland regions of Sarawak, the fallow duration has been shortened and the numbers of cropping in one round of shifting cultivation have been increased with socio-economic alteration. Uses of fertilizers and herbicides have been widespread and their application rates have increased (Kendawang et al. 2005b). This intensified shifting cultivation system might affect vegetation conditions and compositions, probably causing changes in the farmers' perceptions of plants and knowledge on site-selection methods. Further studies should be undertaken to clarify site-selection methods and to incorporate the farmers' knowledge into agricultural development and forest conservation schemes on a community basis.

ACKNOWLEDGEMENTS This study was supported by a Grant-in-Aid for Scientific Research from the Japan Society for the Promotion of Science (No. 13575038 and 17405031) and a grant from the Toyota Foundation. We wish to thank the Director and staff of the Forest Department, Sarawak and Forest Research Center, Sarawak Forestry Corp. for assistance that they provided during this study. We also wish to thank the residents of Rh. Along, Rh. Liok, Rh. Peter, Rh. Anding and $\mathrm{Rh}$. Nawin for their cooperation, hospitality and assistance during surveys.

\section{REFERENCES}

Andriesse, J.P. \& Schelhaas, R.M. 1987a. A monitoring study of nutrient cycles in soils used for shifting cultivation under various climatic conditions in tropical Asia. II. Nutrient stores in biomass and soil -results of baseline studies. Agriculture Ecosystems and Environment, 19: 258-310.

Andriesse, J.P. \& Schelhaas, R.M. 1987b. A monitoring study of nutrient cycles in soils used for shifting cultivation under various climatic conditions in tropical Asia. III. The effects of land clearing through burning on fertility level. Agriculture Ecosystems and Environment, 19: 311-332. 
Bruun, T.B., Mertz, O. \& Elberling, B. 2006. Linking yields of upland rice in shifting cultivation to fallow length and soil properties. Agriculture Ecosystems and Environment, 113: 139-149.

Department of Irrigation and Drainage, 2003. Hydrological Year Book. Dept., Irrigation and Drainage, Sarawak, Kuching.

Dufrêne, M. \& Legendre, P. 1997. Species assemblages and indicator species: the need for a flexible asymmetrical approach. Ecological Monographs, 67: 345-366.

Eghenter, C., Sellato, B. \& Devung G.S. 2003. Introduction. In: Social Science Research and Conservation Management in the Interior Borneo. (eds. Eghenter, C., Sellato, B. \& Devung G.S.), pp. 1-33. WWF Indonesia, Bogor Barat.

Freeman, J.D. 1955. Iban Agriculture: A Report of the Shifting Cultivation of Hill Rice by the Iban of Sarawak. H. M. Stationery Office, London.

Freeman, J.D. 1970. Report on the Iban. Athlone Press, Univ. London, London.

Giardina, C.P., Sanford, Jr.R.L., Døckersmith, I.C. \& Jaramillo, V.J. 2000. The effects of slash burning on ecosystem nutrients during the land preparation phase of shifting cultivation. Plant and Soil, 220: 247-260.

Gönner, C. 2002. A Forest Tribe of Borneo. Man and Forest Series 3, D.K. Printworld (P) Ltd., New Delhi.

Hashimoto, T., Kojima, K., Tange, T. \& Sasaki, S. 2000. Changes in carbon storage in fallow forests in the tropical lowlands of Borneo. Forest Ecology and Management, 126: 331-337.

Ipor, I.B. \& Tawan, C.S. 2004. Succession of fallows after shifting cultivation in Sungai Sarawak basin, Kuching, Sarawak. In: Sustainable Production of Wood and Non-wood Forest Products. (eds. Donoghue, E.M., Benson, G.L. \& Chamberlain, J.L.), pp. 19-27. Proceedings of the IUFRO Division 5, Research Groups 5.11 and 5.12, USDA Forest Service, Washington D.C. and Pacific Northwest Research Station, Oregon.

Ishizuka, S., Sakurai, K., Sabang, J., Kendawang, J.J. \& Lee, H.S. 2000. Soil characteristics of an abandoned shifting cultivation land in Sarawak, Malaysia. Tropics, 10: 251-263.

Juo, A.S.R. \& Manu, A. 1996. Chemical dynamics in slashand-burning agriculture. Agriculture Ecosystems and Environment, 58: 49-60.

Kendawang, J.J., Tanaka, S., Ishihara, J., Shibata, K.,
Sabang, J., Ninomiya, I., Ishizuka, S. \& Sakurai, K. 2004. Effects of shifting cultivation on soil ecosystems in Sarawak, Malaysia. I. Slash and burning at Balai Ringin and Sabal experimental sites and effect on soil organic matter. Soil Science and Plant Nutrition, 50: 677-687.

Kendawang, J.J., Tanaka, S., Shibata, K., Yoshida, N., Sabang, J., Ninomiya, I. \& Sakurai, K. 2005a. Effects of shifting cultivation on soil ecosystems in Sarawak, Malaysia. III. Results of burning practice and changes in soil organic matter at Niah and Bakam experimental sites. Soil Science and Plant Nutrition, 51: 515-523.

Kendawang, J.J., Tanaka, S., Soda, R., Logie, S., Wasli, M. E. \& Sakurai, K. 2005b. Difference of rice farming practices of the Iban in a national boundary area in Borneo and its socio-economic background. Tropics, 14: $295-307$.

Kendawang, J.J., Ninomiya, I., Tanaka K., Ozawa, T., Hattori, D., Tanaka S. \& Sakurai, K. Effects of burning strength in shifting cultivation on early stage of secondary succession in Sarawak, Malaysia. Tropics, 16: (accepted for publishing)

Kuo, S. 1996. Phosphorus. In: Method of Soil Analysis. Part 3-Chemical Methods. (eds. Sparks, D.L., Page, A.L., Helmke, P.A., Loeppert, R.H., Soltanpour, P.N., Tabatabai, M.A., Johnston, C.T. \& Sumner, M.E.), pp. 869-919. Soil Sci. Soc. America, Inc. and American Soc. Agronomy, Inc., Wisconsin.

Mackie, C. 1986. The landscape ecology of traditional shifting cultivation in an upland Bornean Rainforest. In: Proceedings of Workshop on Impact of Man's Activities of Tropical Upland Forest Ecosystems, pp. 425-464. Faculty of Forest, Malaysia Agriculture University, Serdang.

Meteorological Department, 2003. Weather Data (Air Temperature) 1990-2000. Meteorological Dept., Sarawak, Kuching.

Mulvaney, R.L., 1996. Nitrogen-Inorganic forms. In: Method of Soil Analysis. Part 3-Chemical Methods. (eds. Sparks, D.L., Page, A.L., Helmke, P.A., Loeppert, R.H., Soltanpour, P.N., Tabatabai, M.A., Johnston, C.T. \& Sumner, M.E.), pp. 1123-1184. Soil Sci. Soc. America, Inc. and American Soc. Agronomy, Inc., Wisconsin.

Ohta, S., Morisada, K., Tanaka, N., Kiyono, Y. \& Effendi, S. 2000. Are soils in degraded Dipterocarp Forest Ecosystems Deteriorated? A comparison of Imperata grasslands, degraded secondary forests, and primary forests. In: Rainforest Ecosystems of East 
Kalimantan. (eds. Guhardja, E., Fatami, M., Sutisna, M., Mori, T. \& Ohta, S.), pp. 49-57. Springer-Verlag, Tokyo.

Okimori, Y. \& Matius, P. 2000. Tropical secondary forest and its succession following traditional slash-andburn agriculture in Mencimal, East Kalimantan. In: Rainforest Ecosystems of East Kalimantan. (eds. Guhardja, E., Fatami, M., Sutisna, M., Mori, T. \& Ohta, S.), pp.185-197. Springer-Verlag, Tokyo.

Soil Survey Staff, 1999. Keys to Soil Taxonomy. 8th edition. US Dept. Agric. and Natural Resources Conservation Service, Washington, D.C..

Tanaka, S., Ando, T., Funakawa, S., Sukhrun, C., Kaewkhongkha, T. \& Sakurai, K. 2001. Effect of burning on soil organic matter content and $\mathrm{N}$ mineralization under shifting cultivation system of Karen people in northern Thailand. Soil Science and Plant Nutrition, 47: 547-558.

Tanaka, S., Funakawa, S., Kaewkhongkha, T., Hattori, T. \& Yonabayashi, K. 1997. Soil ecological study on dynamics of $\mathrm{K}, \mathrm{Mg}$, and $\mathrm{Ca}$, and soil acidity in shifting cultivation in northern Thailand. Soil Science and Plant Nutrition, 43: 695-708.

Tanaka, S., Kendawang, J.J., Ishihara, J., Shibata, K., Kou, A., Jee, A., Ninomiya, I. \& Sakurai, K. 2004. The effects of shifting cultivation on soil ecosystems in Sarawak, Malaysia. II. Changes in soil chemical properties and runoff water at Balai Ringin and Sabal Experimental sites. Soil Science and Plant Nutrition, 50: 689-699.

Tanaka, S., Kendawang, J.J., Yoshida, N., Shibata, K., Jee, A., Tanaka, K., Ninomiya, I. \& Sakurai, K. 2005. Effects of shifting cultivation on soil ecosystems in Sarawak, Malaysia. IV. Chemical properties of the soils and runoff water at Niah and Bakam experimental sites. Soil Science and Plant Nutrition, 51: 525-533.

Tanaka, S., Wasli, M.E., Seman, L., Jee, A., Kendawang, J.J. \& Sakurai, K. 2007. Ecological study on site selection for shifting cultivation by the Iban of Sarawak, Malaysia. A case study in Mujong River area. Tropics, 16: 357-372.

Teng, S.C. 2003. Classification and management of the steepland for agriculture in Sarawak. Soil Management Branch, Dept. Agr., Sarawak, Kuching.

Tun Jugah Foundation, 2001. Botany. In: The Encyclopaedia of Iban Studies. Vol. I, Tun Jugah Foundation, Kuching, pp. 239-262.

UNCED, 1992. Principle 22. In: Rio Declaration on Environment and Development. UNCED, Rio de
Janeiro.

Yin, E.H. 1992. Geological Map of Sarawak. 2nd Edition. Geological Survey of Malaysia, Kuala Lumpur.

Received $13^{\text {th }}$ Dec. 2006

Accepted $24^{\text {th }}$ Mar. 2007 